\title{
Comparison of Educational Inspectors' Role of Program Leadership in the Foundation Period of Republic of Turkey with Today
}

\author{
Mehmet Emin Usta \\ Faculty of Education, University of Harran, Şanlıurfa, Turkey
}

Copyright $(2018$ by authors, all rights reserved. Authors agree that this article remains permanently open access under the terms of the Creative Commons Attribution License 4.0 International License

\begin{abstract}
From the very early periods of accepting management as a science, main goal of inspection is seen as a control mechanism. Classical management approach evaluated staff as people who need strict inspections by experts to better perform since they are perceived as unreliable and irresponsible on their duties. Later on, expertise areas related to inspection were established and these experts were given inspector names. Education has been one of those expertise fields that started to have inspectors in its particular area. This study focused on curriculum leadership of education inspectors in Turkish Republic era. Because it is to establish the system of the Republic established after the fall of the Ottoman Empire and win the belief of the people to protect this system and to form a people who believe in the Republican system. The most powerful means of creating the people by believing in the republic system was the education system. Inspectors have been seen as the means by which the educational site is mediated for this purpose, teachers and the public as a means of believing in it. Therefore, many tasks were assigned to the education inspectors during this period. In this regard, a document dated 1926, named as 'Instructions about Curriculum in Primary Schools', was obtained from General Directorate of State Achieves and transcribed into Turkish Latin alphabet. In this official document, the roles of educational inspectors as a part of their curriculum leadership for primary schools are defined as increasing the frequency of inspections on whether new curriculum, at that time, was implemented properly or not and ageing increasing the frequency of getting in touch with teachers in order to receive feedback about the curriculum and to support reaching the targets of the curriculum.
\end{abstract}

Keywords Instructional Curriculum, Educational Inspectors, Curriculum Leadership

\section{Introduction}

Inspection is a management function that aims to introduce deficiencies and deficiencies by following the tasks of an occupation in an organization and to take necessary precautions to correct them and to introduce innovations. Inspection requires an inspector to perform his / her duties as administrator, leader, guide, instructor and researcher [10]. According to Karagözoğlu [6], educational inspections are the period in which inspectors or administrative officers provide professional assistance and guidance to teachers and other stakeholders with the aim of increasing the efficiency of schools.

If considered as a managerial process, inspection is the arrangement of items such as input, process and output of the system towards the benefit of the organization. The success of organizations that do not take into account the results of their inspection depends on coincidence and chance. Inspection process succeeds from coincidence, makes it systematic and planned [3]. The objectives of the audit according to the research are three dimensions in terms of quality control, professional development and teacher motivation [9]. In order for these three dimensions to be realized, some psychological attitudes are also needed.

The main institution responsible for educational inspections in Turkey is the Ministry of National Education (MEB). MEB exercises this function by the supervisory staff. According to Inspection Board Regulation $10 / \mathrm{e}$ article, among the duties of the inspectors, "to check the level of coordination between the relevant teachers and to provide guidance, to determine the measures to be taken and to provide information to the Ministry to ensure that the teaching programs are processed in integrity and that different practices which may cause level differences are not included" [5]. In both this regulation and the regulations and guidelines issued at different times, it is frequently emphasized that the maarif inspectors lead the program. 
According to Aydin [2], these psychological attitudes are the inspiration of the teacher to encourage teachers to play a leadership role in various aspects of school programs and to create an environment of mutual trust and respect. According to Wanzare and Costa [11], one of the key roles of education inspectors is to provide support to both developers and practitioners in developing curriculum programs.

According to Şişman [13], some of the roles that should be shown in relation to the training program during the training inspections are: 1. Establishment of the training program of the school: Generally, the schools are ready for the training programs. School programs in Turkey have already been prepared. However, there should be a certain level of autonomy in the creation of each school program. Quality education is a result of events that are planned and arranged in advance. 2. Consideration of Expectations in the School Program: The prepared school program should take into account the expectations of the student, the family-parent, the school environment, the business world, the country and the globalizing world. 3. Coordination between School Programs: The success of the school and the school program depends on the compatibility of the various programs within the school and the coordination between the programs. 4. Provision of Program-Related Materials: In order to achieve the expected level of learning products in the school, education programs, printed materials, educational technologies, physical and financial resources, teaching staff and time should be effectively integrated as main inputs. 5. Concentration on Basic Skills in the Program: It is important to emphasize and concentrate on behaviors at the level of basic knowledge, skills, attitudes and habits envisaged to be given to the students in the preparation and implementation of the school program.

Training programs are constantly changing. For this reason, it is expected that school administrators and inspectors will have enough information about the program because school administrators and inspectors who have sufficient knowledge about the program can provide adequate guidance to their teachers. Inspectors, schools and all stakeholders within and outside the school should strengthen the communication between the inspectors, the teachers and the school stakeholders in order to implement the education programs in the direction of the vision and mission of the school [14].

All educators agree when the school or program leadership increases the quality of education. In this respect, education inspectors have a very important role to play. Educational inspectors are developing not only teachers but also students with the knowledge they have [15].

\section{Education Inspectors in Turkey}

After the opening of the Turkish Grand National Assembly, on May 1, 1920, all of the national education services were given to the Ministry of Education. In 1923, Instruction on Education Inspectors and Instruction on the Duties of Primary Education Inspectors were published. In the instruction of the education inspector, the inspectorate's establishment, the inspectorate duties and authorities and the principles of inspection are explained. In the same year, an Inspection Board composed of a supervisory board director and ten inspectors was established [16]. On May 20, 1925, a meeting of the Inspector General of Education was held and the Regulation on the Inspector General of Education approved by the Council of Ministers was prepared. This Regulation envisages the appointment of Assistant Inspectors to supervise all educational institutions on behalf of the Minister of Education in accordance with laws, regulations and regulations (Karagözoğlu, 1977). In 1926 the Law No. 789 of the Ministry of Education was enacted. According to this definition, a regulation on the rights, powers and duties of the education inspectors has been prepared (İmren, 2017).

The main institution responsible for educational inspections in Turkey is the Ministry of National Education (MEB). Ministry of National Education (MEB) exercises this function by the supervisory staff. 10 / e of Inspection Board Regulation, among the duties of the inspectors, "to check the level of coordination between the relevant teachers and to provide guidance, to determine the measures to be taken and to provide information to the Ministry to ensure that the teaching programs are processed in integrity and that there are no different applications" [18]. In both this regulation and the regulations and guidelines issued at different times, it is frequently emphasized that the maarif inspectors lead the program.

With the Decree of Law No. 6764 dated 02/12/2016 in Turkey, the Presidencies of the Inspectorates of Education established within the Provincial National Education Directorates have been abolished. Instead, a Board of Inspectors composed of ministry ministry inspectors and ministry assistant inspectors were established in the center [18].

In developed countries there are different applications depending on the situation of education inspectors. "The programme of the school and the performance of principals and teachers may also be regularly scrutinised through personnel assessment or inspectorial visits by central authorities or their delegates." [16]. The form of inspection varies by country. For example, in the Netherlands, "the Inspectorate in Primary Education conducts formal visits to produce a quality card for each school. The results are published in league tables in national newspapers ... . In England every school is inspected on a regular cycle by the Office for Standards in Education (OFSTED). ... The system in Flanders combines school self-evaluation with a complementary external assessment by the inspectorate [including] undertaking a comprehensive analysis of the coherence between national curricular objectives and the schoolwork plan .... Greece has opted for only school 
self-evaluation due to its traditional rejection of external inspection ...." [16], [25].

\section{Purpose of the Study}

One of the most up-to-date discussions on the education system in Turkey is the question of how the audit system should be, who controls it, what the competencies of the auditors should be, and what supervisors control. According to the provisions of the Decree on the Organization and Duties of the Ministry of National Education dated 02/12/2016 dated 02/12/2016 and according to the provisions of the Decree of the Ministry of National Education, the duties of the Ministry of Education Inspectors are determined as guidance, training, inspection, evaluation, investigation and investigation.

The purpose of this study is to reveal some information on the role of educational inspectors' program leadership in the foundation period of the Republic based on documents and to compare them with the present. Within this scope, a document numbered 180-09-111-540-1-4, among hundreds of documents taken from the Prime Ministry Ottoman Archives, was transcribed. Following this process, the findings and expectations of the program leadership roles of the educational inspectors in the document were discussed and evaluated by the author. In this context, the relevant document has been converted to the Latin alphabet (Appendix 1), English version (Appendix 2) and the document has been added to the original work (Appendix $3)$.

This research aims to compare the provisions of the "Instruction on New Curriculum Programs of Primary Schools" of 1926 with the current situation. To this end, the following questions were answered:

1. What are the provisions of the 1926 Primary Schools Regarding the Inspection of the New Curriculum Programs?

2. What are the regulations regarding school inspection today?

3. What are the similarities and differences between the program inspectors' program leadership in the early Republican period?

\section{Method}

This study, titled "Program Leadership Roles and Comparing to the Present", is the documentary screening model. Screening models are research models that try to present the past or present situation as it exists. In these models, evidence is gathered with the purpose of establishing facts, establishing relations and judging about past events. These evidences are historical data sources. Historical sources of data may be written and printed documents, as well as related relics [7]. Qualitative research method was also used in the study. The qualitative research method is considered as a type of research in which the methods such as observation, interview and document analysis are used, perceived, and monitored in a realistic and holistic manner in the natural environment [12].

The use of the documentary screening model in the research relates to the spirit of historical research. Documentation must be provided in order to be able to present historical records. These documents should be simplified in language. Then, if compared with today, documents related to the subject should be found and compared today. Certain judgments must be made after the comparison is made. In this research, the following stages were followed in accordance with the documentary screening model:

1. A literature study on the subject has been made and the information given in the introduction section.

2. Historical documents contained documents or documents that shed light on the subject.

3. The relevant document has been translated from Ottoman to Latin alphabet.

4. Current legal texts related to the subject have been reached.

5. In the light of the relevant literature, the old and new documents were compared and some results were obtained.

\section{Results}

\section{Findings of the Founding Period of the Republic}

In the early years of the Republic, the leadership roles of the education inspectors were regarded as very important. The Ottoman Empire was destroyed. The Republic system was established instead. The people are still in war. War is the place where people have memories. The Republican system wants to create a new understanding of education and root it in the present. Towards this end, teachers are seen as a change agent. Akyüz [17] refers to Mustafa Necati at the time as minister of education: Teachers forget the main purpose to be done with the education system. They prefer to use only the narration method and try to memorize the students. They do not even do experiments in science classes. Students do not research and observe themselves. For this reason, there is no scientific approach in our students. Mustafa Najati bases these determinations on reports given by educational inspectors. Moving from these findings, it is possible to say that the program leader of education inspectors seems to be very important in the early Republican period.

According to the document dated 1926 from "Instruction about the New Jobs Curriculum Programs of Primary Schools", the primary school curriculum has been changed by the National Education and Training Office on the mentioned date. It is emphasized that the program, which is called curriculum program, differs from the previous curriculum in that it adopts the collective teaching method 
in the first three years, the student is more active and has a close relationship.

According to the instructions, the new curriculum will be implemented across the country, only in the first three years of five-year primary schools. In the fourth and fifth grades, the old curriculum will be applied this year (1926). In addition, each department or office will appoint schools to administer the new program and will report their names to the representatives through the teacher's confidences.

During the implementation of the new program, which was developed in 1926, education inspectors were asked to pay particular attention to the following points:

New curriculum programs and liaison duties will be read carefully from beginning to end by every elementary school teacher and care will be taken to ensure that these programs are always in contact with core / base courses. No teacher will see himself as responsible for his / her own lessons, and lessons will be processed by contacting other lesson teachers. The inspectors will be responsible for the supervision of this situation. Primary education inspectors will gather teachers to discuss the new curriculum from start to finish and ensure that teachers have sufficient knowledge.

Primary education inspectors will contribute to the frequent inspections of schools implementing new programs and to reach as many programs as possible by contacting the teachers as much as possible. New curriculum programs also include teaching procedures and advice. Despite this, an ambiguous situation at the beginning can be explored directly by applying to the national training and training circle. The aim of the program can only be achieved through the sequential processing of the units mentioned in the lessons of life lessons, the unification of lessons and the capture of harmony.

The points to which the application of the new programs will be respected will be taken into consideration in general, but the reports that the primary education inspectors will give every three months. Primary education inspectors will inspect and control the implementation of the programs on a regular basis, and the result will be reported to the Education and Training Department.

To summarize, during the foundation period of the Republic, educational inspectors are expected to:

1. The conviction of the people through the education system to the ideals of the Republic,

2. Making the education system analytical,

3. Explaining the innovations in the curriculum to the teachers,

4. Provision of school and environment relation,

5. Organizing conferences for teachers,

6. Monitoring teacher performance,

7. Cooperation among teachers,

8. Frequent supervision of schools,

9. The reports prepared under the supervision of the schools are sent to the Ministry of Education.

\section{Findings Related to Today Are Below}

In the process up to 16 August 1997, it is observed that the education structuring in Turkey consists of primary school with 5 years of education, secondary school with 3 years, and high school with 3 years. On August 16, 1997, with the amendment made in National Education Law numbered 1739, elementary schools and secondary schools were unified and uninterrupted education was provided for 8 years. Primary education schools were not changed in the period of secondary education institutions. Again, on March 30, 2012, an amendment was made in Article 24 of the same law and the primary schools were separated into primary and secondary schools with a period of 4 years and the secondary education institutions were also made obligatory for 4 years [18].

Briefly, the 12 year compulsory education curriculum consists of the general objectives that the students are expected to reach for each course, explanations on the methods, techniques and strategies to be used in the process of transferring the knowledge, skills and attitudes to the students, directions and warnings. The curricula also set out the learning objectives that indicate the level of knowledge and skills students need to achieve at each class level. Thus, while the teacher guides in educational leadership, the parents also provide guidance on what to expect from their children [18].

The education system in Turkey is being developed. Comparisons are made for this purpose. For example, one way to analyze education systems is to compare education practices and curricula of different countries with results from international assessments (International Student Assessment Program / PISA and International Mathematics and Science Tendency Survey / TIMSS). Comparisons and surveys conducted prior to the development of the programs revealed striking similarities and distinct differences between the world-class expectations and the standards adopted by Turkey [18].

Along with these efforts everyone agrees when it is necessary to guide teachers today and to have a mechanism to train them at work. From the point of view of our recent history, it is stated among the duties of the Education Inspectors Presidency in the Decree Law on the Organization and Duties of the Ministry of National Education, numbered 652 of 2011, "The issues that fall under the ministry's mission are to guide the Ministry's schools and institutions, private education institutions and real and legal persons ". In the first paragraph of Article 71 of the Regulation on the Presidency of the Ministry of National Education, Guidance and Supervision and the Ministry of Education Inspectorate Regulations, "Presidency, education, teaching and management at the level of the central, provincial and foreign organizations of the Ministry, education indicators, quality standards, performance criteria and self- monitors and assesses the level of implementation of the findings and recommendations contained in the report of the institution, 
which is based on guidance and is audited ". In the 1st paragraph of the 69th article of the same directive, it is stated as "leadership of the education inspectors in the guiding function of the education inspectors" as "guidance is given to the personnel of the Ministry, the staff of the Ministry, schools and institutions, private education institutions, public institutions and organizations, voluntary organizations and real persons and legal entities" attention has been drawn.

As a result, today's educational inspectors are expected to play the following role:

1. Regulation of the education system,

2. Achievement of academic achievement,

3. Success in international exams,

4. Training of teachers at work,

5. It is expected that the teachers will be given leadership in terms of ensuring adaptation to the profession.

\section{Conclusions and Discussion}

It is understood that in 1926, "Instruction on the New Curriculum Programs of Primary Schools", the primary school curriculum was renewed in 1926. It is also possible that the concept of documentary curriculum and curriculum is not new and that these concepts are more than a hundred years old.

As a matter of fact, it is understood that a regulation dated 1909 had the duty to supervise whether the inspectors' education program was exercised as it was during the Ottoman Empire period [19].

It is clear that the renewed primary school curriculum aims to establish a close link between real life and the school. This arrangement can be interpreted as the reflection of the curriculum of the results of the 1924 John Dewey Report. It is also understood that the current practice has adopted the principle that the main courses or the pivotal courses (Science of Living Course) should be applied and the other courses should be processed accordingly.

The said directive sees the instructors as program experts and teacher guides. According to the instruction, inspectors will enlighten teachers on the program and follow program effectiveness. This should be viewed as a clear reference to the role of the curator inspectors' program leadership. When we look at the general practices in the world, it is seen that this situation is shared by education authorities [20].

One of the most striking aspects of the documentary mentioned above is ensuring that the teaching activity among the inspectors' tasks is carried out appropriately. This situation is a reflection of the history of teaching programs. The earliest date is mentioned in the contemporary program development books when the program development process is emphasized in its history [1]. Whereas the above document is dated 1910/1911, it explicitly mentions the teaching program and the follow up of the inspectors' implementation of the program. It is also emphasized that other documents dated April 1, 1895, 3 June 1901 and 20 October 1904 also ensure that the transfer of primary school inspectors and the schools to which the duties of the administrators are assigned are carried out in accordance with the orders and programs [8].

When the documents of the Ottoman Empire covering the dates between the 1st Constitutional Monarchy and the Republican Period were examined, there are also strong references to the educational inspectors' program leadership. For example, 44 documents dated February 14, 1900 and 105 files were documented. Members of the Inspection Board were asked whether they had attended the educational programs related to science and sciences, unnecessary courses or not, the time and attendance of the obligatory worships and whether the necessary precepts are shown in teaching religion and morality and Ottoman history, and whether these courses need to be reformed; it is understood that the task of preparing a report in the result of the inspection and the investigation is given.

It is understood that the 88 documents, 810 files, dated October 20, 1904, provide for the transfer of the schools to which the duties of the primary school inspectors were assigned, and the inspections and training activities of the primary school inspectors in accordance with the orders and programs. 61 documents, dated March 15, 1906, document no. 918, the provincial directorate of education, the primary school and secondary schools, in particular primary school and village school teachers and their duties, whether they continue their duties, whether education has been made in accordance with the education programs and whether the attendance of the students the inspector was requested to be sent.

17 documents dated December 30, 1913, and 190 files, each of the state schools in the state-affiliated provinces or provinces should be instructed by the state to set up programs and lessons to be taught and to be taught by them. In the documentary dated 14 May 1917, the supervision of the orphans and the teaching methods of the teachers, the schedules and the examination results of the inspectors' duties were counted [8].

According to Dewey [4], the responsibility of the inspectors responsible for the supervision of Turkish education is to inform the ministry that the different schools fulfill their duties well, how the teachers are educated and how school buildings and vehicles are used. However, these duties will not serve the purpose of being a source of inspiration and guidance for Turkish education besides being necessary. These inspectors should also be given the task of teaching teachers and administrative officers of schools in different regions. Travel guides and inspectors should be assigned to this purpose [4]. From here it can be shown that Dewey expresses leadership and expertise qualities of inspectors while drawing attention to the roles that education inspectors need to develop.

From the point of view of our recent history, it is stated 
among the duties of the Education Inspectorate in the Decree Law on the Organization and Duties of the Ministry of National Education, numbered 652 and dated 2011, that "the issues that fall under the ministry's mandate ... Guidance to the Ministry's schools and institutions, private education institutions and real and legal persons ". In the first paragraph of Article 71 of the Regulation on the Presidency of the Ministry of National Education, Guidance and Supervision and the Ministry of Education Inspectorate Regulations, "Presidency, education, teaching and management at the level of the central, provincial and foreign organizations of the Ministry, education indicators, quality standards, performance criteria and self- monitors and evaluates the level of implementation of the findings and recommendations contained in the report of the institution, which is based on guidance and is audited. " In the 1st paragraph of the 69th article of the same directive, it is stated as "leadership of the education inspectors in the guiding function of the education inspectors" as "guidance is given to the staff of the Ministry, the staff of the Ministry, schools and institutions, private education institutions, public institutions and organizations, voluntary organizations and real persons and legal entities" attention has been drawn. The research conducted by İmren [21] also pointed out that the curriculum and guidance roles of the education inspectors are included. According to this research, teachers stated that education inspectors cannot provide effective guidance but they should do it. In the study conducted by Bayar [22], it is emphasized that the education inspectors' contribution to the education system is important; the inspections conducted by the inspectors are more objective and the leadership roles. Again, according to the principles of OFSTED, where education inspectors are affiliated in England, education inspectors have to know the training program well and enlighten teachers [23].

Educational inspectors' program leadership is still very important for a strong and quality education system [24]. As a result, it can be judged that the role of the program leader in educational inspectors is still continuing, both in practice and in legal texts, in the foundation years of the Republic, and that this role is due to the ever changing educational needs of teachers and other interested persons.

\section{Appendix 1}

Instruction on the New Curriculum Programs of Primary Schools Inspectors

(Ottoman Latin Alphabet Version)

İlk Mekteplerin Yeni Müfredat Programları Hakkında Talimat

(Başbakanlık Devlet Arşivleri Genel Müdürlüğü İstanbul Osmanlı Arşivi: 180-09-111-540-1-4)

\section{Ankara 1926}

\section{İstanbul Maarif Vekaleti}

\section{Milli Talim ve Terbiye Dairesi}

1. İlk mekteplerin müfredat programları değiştirilmiştir. Yeni programlardan lüzumu kadar nüsha doğrudan doğruya milli matbaadan maarif dairelerine gönderilecektir. $\mathrm{Bu}$ programlar eskilerinden bilhassa şu hususlar itibariyle farklıdır: (1) Yeni programlarda ilk üç senede toplu tedris usulü kabul edilmiştir; (2) Yeni programlar talebenin daha ziyade faal olmasını istihdaf etmektedir; (3) Yeni programlar talebe ile muhit arasında daha sıkı bir rabita husule getirmek esasına müsteniddir.

2. Eski programlardan esaslı bir surette farklı olan yeni programların bu sene her mektebde birden tatbiki muvafik görülmüşdür. Programlar şimdilik her vilayetde yalnız binası ile teşkilatı ve teçhizatı tam olan beş dershaneli mekteplerin ilk üç senesinde tatbik edilecektir. Diğer mektepler ile yeni programın tatbik edileceği mekteplerin ikinci devre (dördüncü ve beşinci) sınıflarında bu sene de eski program dairesinde tedrisatta bulunulacaktır. Ancak her vilayette bu suretle yeni programın tatbik edileceği mekteplerin adedi biri kız mektebi olmak şartıyla en az iki tane olmalıdır. Her maarif müdürlügü veya memurluğu yeni programı tatbik edecek mektepleri tayin ederek isimlerini maarif eminleri vasitasiyla vekalete bildireceklerdir.

3. Yeni programın tatbikinden bilhassa aşağıdaki noktaların itina ile nazarı dikkatte tutulması lazımdır. Tatbikattan istihsal edilecek neticenin kıymeti doğrudan doğruya bunlara gösterilecek itinaya tabidir:

A. Yeni müfredat programları ve irtibat cetvelleri her ilk mektep muallimi tarafından baştan başa dikkatle okunmalıdır. Yeni programlarının başlı vasfı mümeyyiz dersleri arasında daima irtibat ve münasebet bulunmasina atfedilen ehemmiyette görülür. Hiçbir muallim yalnız dersine ait vazifenin hududu içinde ve diğer arkadaşlarının mesaisine lakayd bir halde kalamaz; bunun içindir ki yeni programların tatbik edileceği mekteplerde ilk yapılacak iş, muallimlerin ilk tedrisat müfettişinin riyaseti altında toplanarak yeni müfredatı başından sonuna kadar dikkatle mütalaa, tedkik etmek ve icap eden noktaları hakkında teatii efkar suretiyle programın muhtevası ve maksatları hakkında ..... fikirleri edinmelerini temin eylemektir.

B. Yeni programın tatbik işinde ilk tedrisat müfettişlerine düşen faaliyet hususu ayrıca şayan zikreder. Müfettişler yeni programları tatbik eden mekteplerde tedrisatı sık sık teftiş etmek ve muallimler ile mümkün olduğu kadar fazla temas ederek programların istihdaf ettiği terbiyevi gayelerin teminine çalışmalıdırlar.

C. Yeni müfredat programları usulü tedrise ait tavsiye ve veçheleri de ihtiva etmektedir. Her derse ait ayrıca usul tedrisi risaleleri de peyderpey tertip ve neşr olunacaktır. Ancak bidayette herhangi bir noktada muhtaç izah bir cihet görülürse doğrudan doğruya milli talim ve terbiye dairesine müracaat edilerek izahat istenmelidir. 
Programdan gözetilen maksatların husulü, ancak Hayat Bilgisi derslerinde sira ile rakamla olarak gösterilen ders cüzülerinin sınıf muallimleri tarafından evvelden layıkıyla mütalaa edilmek suretiyle münasip bir plan dahilinde tevsi ihzar olunması ve bunların ikmaline kadar tedrisatı vahdet ve ahenki tam ile devam edilmesi ile mümkündür. Ve bu cihetle kat'en ihmal edilmemesi lazımdır.

4. Yeni programların tatbikine riayet edilecek noktalar yukarıki maddelerde gösterilmiştir. $\mathrm{Bu}$ husustaki faaliyetlerin neticeleri ilk tedrisat müfettişlerinin raporlarına müstenid olan her üç ayda bir vekalete bildirilmelidir.

İlk mekteplerin yeni müfredat programlarına ait talimat karşıki sahifede yazılıdır. Programlar bu talimat dairesinde tatbik edilecek ve tatbikat ilk tedrisat müfettişleri tarafından mütemadiyen teftiş ve murakabe olunarak istihsal edilen neticeleri raporlar ile milli talim ve terbiye dairesine bildirilecektir.

Buna göre hareket olunmasını beyan ederim efendim.

\section{Appendix 2}

\author{
Instruction on New Curriculum Programs for Primary \\ Schools Inspectors \\ (English Version) \\ (Prime Ministry State Archives General Directorate \\ Istanbul Ottoman Archives: 180-09-111-540-1-4)
}

Ankara 1926

Istanbul Ministry of Education

National Training and Education Office

1. Primary school curriculum programs have changed. Copies of new programs will be sent directly from the national printing house to the school directorate. These programs are particularly different from the old ones in the following points: (1) In the first three years of the new program, the collective teaching procedure was accepted;

(2) New programs aim to make the student more active; (3) New programs aim to bring a closer relationship between students and the environment.

2. New programs that differ fundamentally from older programs are considered appropriate to be implemented at each school this year. For the time being, the programs will be implemented in the first three years of each of the five classrooms with full board and facilities and equipment. In the second cycle (fourth and fifth) classes of the schools where the new program will be applied with other schools, this year's curriculum will be given in the framework of the old program. However, the number of schools to which the new program will be applied in each district must be at least two, provided that one is a girl's school. Each educational directorate or officer will appoint the schools that will implement the new program and will notify the ministry through their education directors.

3. Especially in the implementation of the new program, the following points must be carefully observed. The result that will arise from the application is subject to the direct indication to them:

A. New curriculum programs and contact duties should be read carefully from beginning to end by every elementary school teacher. The new courses will always be contacted and established between the pivotal courses and the other courses. The achievement depends on the establishment of this contact. No teacher will be alone in the boundaries of the assignment of the lecture and will not be indifferent to the way of working of the other friends. The first thing to do with the new programs for these schools is to gather them under the supervision of the teachers' primary school inspector and to discuss and research carefully from the beginning to the end of the new curriculum. As a result, they will be provided with ideas about the contents and purposes of the program by exchanging views and thinking about the necessary points.

B. The task of primary school inspectors during the implementation of the new program is also worth mentioning. Inspectors should frequently inspect instruction in schools where new programs are being implemented and should work to ensure that the curriculum aims for the curriculum by contacting as much as possible with the teachers.

C. New curriculum programs have different purposes according to teaching methods. The teaching strategies and course content of each course will be arranged and published separately. However, if there is a situation that needs to be explained at any point in the beginning, it should be requested directly from the national training and education circle.

The purpose of the program is to reach the desired objectives, but the number of courses shown in the sequence of the Life Science courses is known by the class teachers in accordance with the appropriate plan in advance, and their teaching depends on unity and harmony. This direction should not be neglected.

4. The points to be observed in the implementation of the new programs are shown in the above items. The results of such activities shall be communicated to the Ministry every three months based on the reports of the primary education inspectors.

Instructions for new curriculum programs for primary schools are written on the opposite page. The programs will be implemented within the scope of this instruction and the application will be continuously inspected and checked by the primary education inspectors and the results obtained will be reported and reported to the national training and education center.

I declare that you will act accordingly, sir. 


\section{Appendix 3}

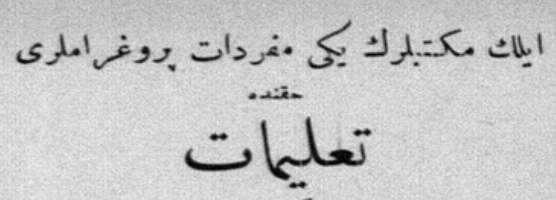



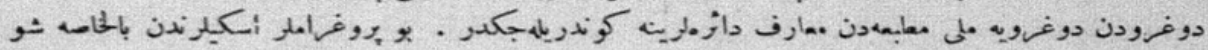

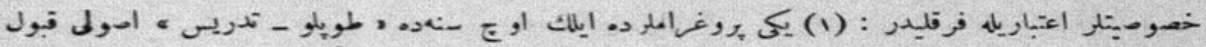



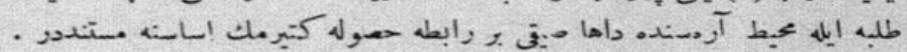

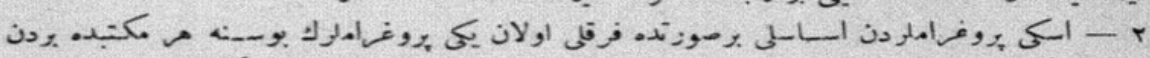

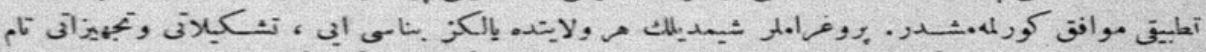



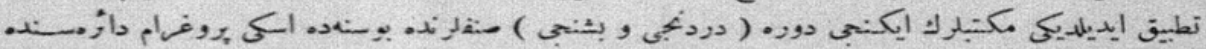

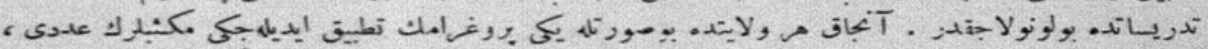

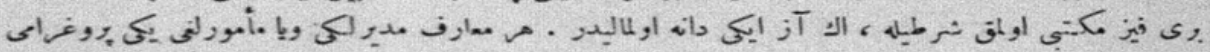

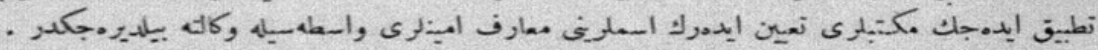

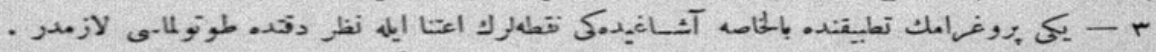

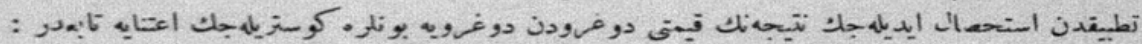

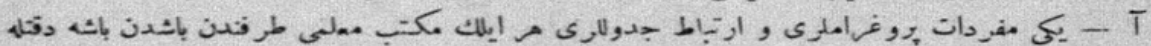

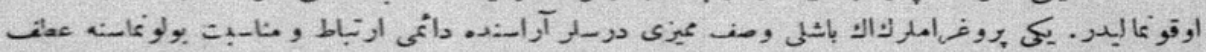

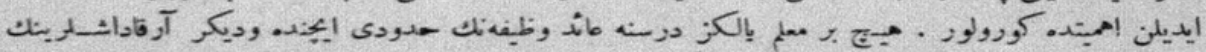

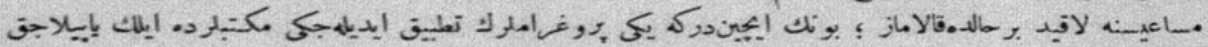

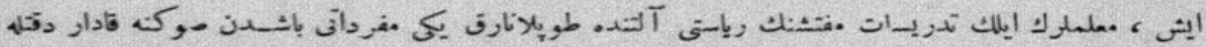

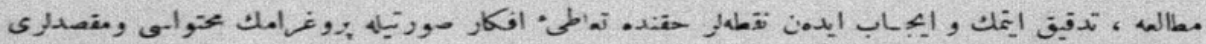
-

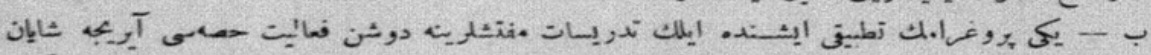

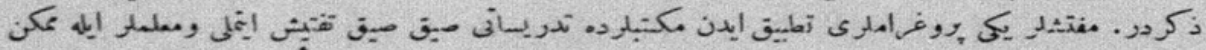



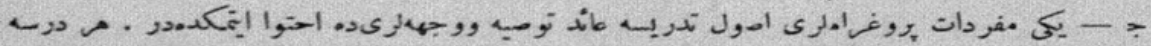

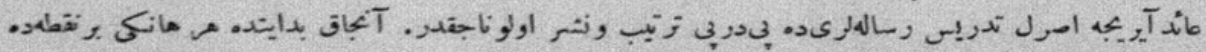

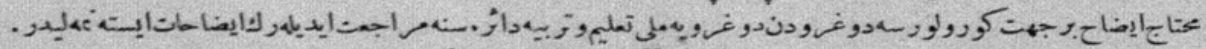

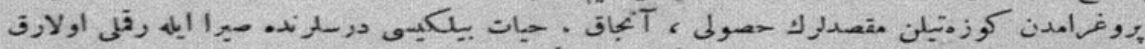



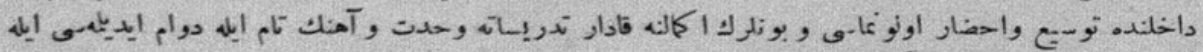



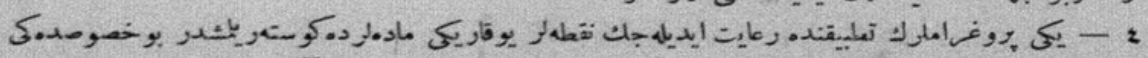








$$
\begin{aligned}
& \text { تانبول معارف وكالى }
\end{aligned}
$$

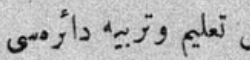

$$
\begin{aligned}
& \text { g }
\end{aligned}
$$

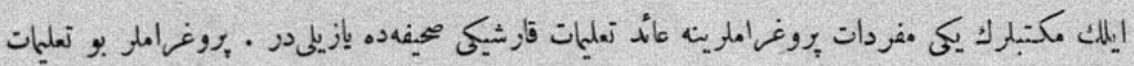

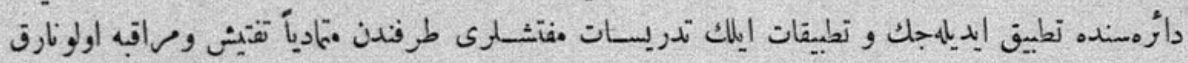

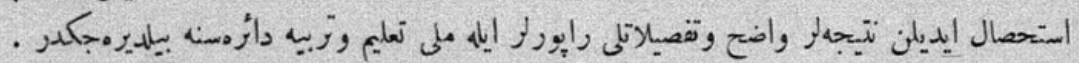

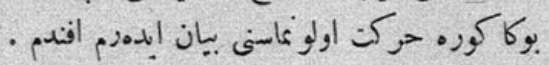

\begin{tabular}{|l|l|l|l|l|}
\hline 180 & 05 & $111 / 50$ \\
\hline
\end{tabular}

Figure 1. Instruction on the New Curriculum Programs of Primary Schools Inspectors (Ottoman Arabic Alphabet Version) 


\section{REFERENCES}

[1] Akpunar, B. (2015). Eğitimde Program Geliștirme. Ankara: Data.

[2] Aydın, M. (1993). Çă̆daş Eğitim Denetimi. Ankara: Pegem Yayinları.

[3] Çakıcı, L. (1985). "Eğitim Yönetiminde Denetleme ve Değerlendirme Sempozyumu”, Ankara Üniversitesi Eğitim Bilimleri Fakültesi Yayınları.

[4] Dewey, J. (1924). Türkiye Maarifi Hakkında Rapor. https://www.tbmm.gov.tr/eyayin/GAZETELER/WEB/KU TUPHANEDE\%20BULUNAN\%20DIJITAL\%20KAYNA KLAR/KITAPLAR/DIGER\%20YAYINLAR/197000571 \%20TURKIYE\%20MAARIFI\%20HAKKINDA\%20RAP OR\%20(JOHN\%20DEWEY)/0000 0000\%20TURKIYE\% 20MAARIFI\%20HAKKINDA\%20RAPOR\%20(JOHN\%2 ODEWEY).pdf Date of access: 31 March 2017.

[5] http://tkb.meb.gov.tr/www/mevzuat/icerik/23 Date of access: 31 March 2017.

[6] Karagözoğlu, G. (1972). Türk Ĕ̆itim Düzeninde Bakanlı Müfettişlerinin Rolü Araştırma Özeti. Ankara: MEB Planlama Araştırma ve Koordinasyon Dairesi.

[7] Karasar, N. (1997). Bilimsel Araştırma Yöntemi. 9. Baskı. Ankara: Nobel Yayın Dağıtım.

[8] Özmen, F., Açıkses, E., Usta, M. E. ve Uluerler, S. (2004). Meşrutiyetin İlanından, Cumhuriyet Dönemine, Osmanl Devleti’nde Eğitim Denetimi (1876-1923). Frrat Üniversitesi Bilimsel Araştırmalar Birimi Koordinasyon Birini. Proje no:1845.

[9] Sergiovanni T. J. \& Starratt R. J. (2007). Supervision: A Redefinition, New York: McGraw-Hill.

[10] Taymaz, H. (2010). Eğitim Sisteminde Teftiş (7. Baskı). Ankara: PegemA.

[11] Wanzare, Z. and Costa, J. L. (2000). "Supervision and Staff Development: Overview of the Literature". National Association of Secondary School Principals. NASSP Buletin: Oct. 2000: 84, 618: ProQuest Education Journals, 47-54.

[12] Yıldırım, A. \& Şimşek, H. (2008). Sosyal Bilimlerde Nitel Araştırma Yöntemleri (6. Bask1). Ankara: Seçkin.

[13] Şişman, M. (2002). Öğretim Liderliği. Ankara: PegemA.

[14] Yaraş, Z. (2013). İlkokul Yöneticilerinin Program Liderliği Davranışlarını Gösterme Düzeylerinin Kolektif Yeterlik Algısına Ve Örgütsel Öğrenme Düzeyine Etkisi. Yüksek Lisans Tezi. Frrat Üniversitesi, Elazığ.

[15] https://leadershiphub.etfoundation.co.uk/sites/default/files/ inline-files/Ofsted_annual_report_education_and_skills.pd f Date of access: $1 \overline{1}$ Oct $20 \overline{17}$.

[16] http://www.oecd.org/edu/school/37133393.pdf Date of access: $110 c t 2017$

[17] Akyüz, Y. (2013). Türk Eğitim Tarihi. Ankara: PegemA.

[18] http://mufredat.meb.gov.tr/SSS.aspx Date of access: 11Oct 2017.

[19] Tümer Erdem, Y. (2009). Osmanlı Eğitim Sisteminde Teftiş. Osmanlı Tarihi Araştırma ve Uygulama Merkezi Dergisi. Say1: 26. s:55-93.

[20] https://www.gov.uk/government/news/the-importance-of-1 eadership-in-the-education-and-skills-system Date of access: 11 Oct 2017.

[21] İmren, S. (2017). Öğretmenlerin Mesleki Gelişiminde Maarif Müfettişlerinin Eğitim - Öğretim İle İlgili Rehberlik Rolleri (Van İli Çaldıran İlçesi Örneği). Yüksek Lisans Tezi. Abant İzzet Baysal Üniversitesi, Bolu.

[22] Bayar, T. (2017). Maarif Müfettișlerinin Sinıflarda Uyguladığı Rehberlik Ve Denetim Uygulamalarının Kaldırılmasına İlişkin Öğretmen Okul Müdürü Ve Maarif Müfettişlerinin Görüșleri. Yüksek Lisans Tezi. Mehmet Akif Ersoy Üniversitesi Eğitim Bilimleri Enstitüsü, Burdur.

[23] https://publications.parliament.uk/pa/cm201617/cmselect/c meduc/170/170.pdf Date of access: 11Oct 2017.

[24] https://www.gov.uk/government/news/the-importance-of-1 eadership-in-the-education-and-skills-system Date of access: 11 Oct 2017.

[25] https://www.gov.uk/government/uploads/system/uploads/a ttachment_data/file/482882/The_report_of_Her_Majesty_s Chief Inspector of Education Children s Services an d_Skills_Schools.pdf Date of access: 11 Oct 2017 . 